\title{
TANGGUNG JAWAB PELAKU USAHA MASKAPAI PENERBANGAN ATAS PENUNDAAN PEMBAYARAN DANA REFUND
}

\author{
Dinda Aurelia Danian, Ni Luh Made Mahendrawati, Ida Ayu Putu Widiati \\ Fakultas Hukum Universitas Warmadewa, Denpasar-Bali, Indonesia
}

\begin{abstract}
Abstrak
Persaingan mendorong perusahaan memberikan penawaran-penawaran menarik seperti harga tiket promo hingga pemberian kursi secara gratis. Akan tetapi, banyak perusahaan maskapai penerbangan yang hanya ingin mencapai target profit, rela mengesampingkan tanggung jawab dan hak-hak konsumen; salah satunya adalah penundaan pengembalian dana (Refund) tiket penerbangan akibat pembatalan penerbangan (cancelation of flight) yang dilakukan oleh pihak maskapai penerbangan secara sepihak. Penelitian bertujuan untuk mengetahui bentuk perlindungan hukum terhadap konsumen yang mengalami penundaan pembayaran dana Refund oleh maskapai penerbangan dan mengetahui bentuk tanggung jawab maskapai penerbangan terhadap dana Refund dan upaya penyelesaian apabila terjadi sengketa. Jenis penelitian ini adalah yuridis normatif dengan pendekatan perundang-undangan yang disajikan dalam bentuk interpretasi hukum. Hasil penelitian menunjukan bahwa pembatalan jadwal penerbangan oleh maskapai penerbangan tidak diatur dalam Undang-undang No. 1 Tahun 2009 tentang Penerbangan namun dapat dilihat ketentuannya pada Permenhub Nomor 77 Tahun 2011 Pasal 12 ayat 1 dan 2. Permenhub Nomor 185 Tahun 2015 juga mengatur tentang jangka waktu pengembalian uang tiket. Pengembalian refund juga dapat ditambah kompensasi lainnya sebagaimana Pasal 1453 KUHPerdata. Jangka waktu proses pengembalian dana oleh maskapai penerbangan umumnya sudah sesuai dengan Peraturan Menteri Perhubungan Nomor 185 Tahun 2015. Penyelesaian sengketa konsumen dapat dilakukan dengan 1) Pergantian kerugian secara langsung; 2) Melalui BPSK dengan jalan mediasi, konsiliasi dan arbitrase; 3) Penyelesaian sengketa konsumen melalui jalur litigasi.
\end{abstract}

Kata kunci: perlindungan konsumen, penundaan refund, penyelesaian sengketa

\begin{abstract}
Competition encourages companies to provide attractive offers such as promo ticket prices to giving free seats. However, many airline companies, who only want to achieve their profit targets, are willing to put aside their responsibilities and consumer rights; one of which is the delay of a flight ticket refund due to the cancellation of the flight by the airline unilaterally. This study aims to determine the form of legal protection for consumers who experience delays in paying Refund funds by airlines and to find out the forms of airline responsibility for Refund funds and settlement efforts in case of disputes. This type of research is normative juridical with a statutory approach presented in the form of legal interpretation. The results showed that the cancellation of flight schedules by airlines was not regulated in Law No. 1 of 2009 concerning Aviation, but the provisions can be seen in the Minister of Transportation Regulation Number 77 of 2011 Article 12 paragraphs 1 and 2. Permenhub Number 185 of 2015 also regulates the period of ticket refunds. Refunds can also be added with other compensation as well as Article 1453 of the Civil Code. The time period for the refund process by airlines is generally in accordance with the Regulation of the Minister of Transportation Number 185 of 2015. Settlement of consumer disputes can be done by 1) Direct compensation for losses; 2) Through BPSK by means of mediation, conciliation and arbitration; 3) Settlement of consumer disputes through litigation.
\end{abstract}

Keywords: Consumer protection, Delay refund, Dispute resolution

\section{PENDAHULUAN}

Pasar yang paling ideal dan dapat meningkatkan pertumbuhan ekonomi suatu negara adalah pasar persaingan sempurna, namun idealisme pasar tersebut tidaklah mudah untuk dicapai karena dalam praktiknya hal tersebut akan bersinggungan dengan perilaku pelaku usaha yang lebih banyak memegang prinsip keuntungan ekonomi, yaitu dengan modal sekecil-kecilnya untuk dapat menghasilkan keuntungan yang sebesar-besarnya (Mahendrawati, 2018:3). Salah satu esensi penting bagi terselenggaranya pasar bebas yakni persaingan para pelaku pasar dalam memenuhi kebutuhan konsumen. Untuk merebut hati konsumen, pelaku usaha berusaha menawarkan produk dan jasa yang menarik, baik dari segi harga, kualitas, dan pelayanan (Mahendrawati, 2018:17). 
Persaingan mendorong perusahaan maskapai penerbangan memberikan penawaran-penawaran menarik seperti harga tiket promo hingga pemberian kursi secara gratis, tetapi banyak perusahaan maskapai penerbangan yang hanya ingin mencapai target profit, rela mengesampingkan tanggung jawab dan hak-hak konsumen salah satunya adalah penundaan pengembalian dana (refund) tiket penerbangan akibat pembatalan penerbangan (cancelation of flight) yang dilakukan secara sepihak oleh pihak maskapai penerbangan.

Penerbangan merupakan jenis transportasi udara yang paling banyak diadukan oleh konsumen. Istilah konsumen merupakan alih bahasa dari kata consumer (Inggris-Amerika) atau consument/konsument (Belanda) yang secara harafiah adalah lawan dari produsen (Kristiyanti, 2019:22). Yayasan Lembaga Konsumen Indonesia (YLKI) menyatakan bahwa 61 pengaduan datang dari transportasi udara, darat 22 aduan, dan angkutan laut 1 aduan. Konsumen pun mengeluhkan permasalahan pengembalian (refund) tiket karena berbagai alasan (https://m.liputan6.com/bisnis/read/2166024/lion-air-dan-refund-tiket-paling- banyak-diadukankonsumen-ke-ylki diakses tanggal 7 Oktober 2019). Sebagai contoh kasus atas indikasi pelanggaran yang dilakukan oleh pihak maskapai kepada penumpang adalah terjadi kepada sdri. Dinda dengan pihak maskapai Air Asia.

Kejadian tersebut diawali dengan pihak Air Asia memberikan promo iklan penerbangan murah pulang pergi dengan rute Internasional Denpasar (Bali) menuju Narita (Jepang) di Web Resmi mereka. Dengan promo penerbangan berbiaya murah tersebut sdri. Dinda tertarik untuk membeli tiket penerbangan tersebut tertanggal 25 mei 2018 dengan jadwal keberangkatan tanggal 08 april 2019 dan jadwal pulang pada tanggal 15 april 2019 seharga Rp.2.490.000,00. Setelah sdri. Dinda telah melakukan pembayaran secara penuh ke pihak maskapai sesuai dengan kewajiban penumpang, maka E-ticket terbit dengan Booking Number: IL2TQF. Tentu dengan telah terbitnya E-ticket ini membuat sdri. Dinda lega dengan harapan bahwa penerbangan dapat terlaksana sesuai dengan jadwal keberangkatan yang telah sdri. Dinda pesan. Namun, pada tanggal 22 oktober 2018 sdri. Dinda mendapat pemberitahuan melalui email bahwa telah terjadi pembatalan penerbangan secara sepihak oleh pihak maskapai Air Asia yang disebabkan oleh adanya restrukturisasi jaringan penerbangan dengan memberikan beberapa pilihan layanan kompensasi yang diantaranya adalah memberika pilihan pengembalian dana secara penuh (Full Refund). Pada saat itu sdri. Dinda memutuskan untuk memilih layanan kompensasi dengan pengembalian dana secara penuh dengan mengisi E-Form untuk pengajuan full refund sesuai dengan aturan maskapai tersebut dan akan dijanjikan dana akan diterima dengan jangka waktu maksimal 180 hari. Akhirnya setelah sekian lama sdri. Dinda menunggu, tidak ada kejelasan sama sekali yang diberikan oleh Air Asia kepada sdri.Dinda, maka sdri. Dinda berupaya memperjuangkan menuntut haknya dengan terus mencari tahu bagaimana kelanjutan pengembalian dana sdri. Dinda kepada petugas maskapai Air Asia, baik melalui sambungan telpon call center maupun layanan Live Chat yang disediakan pada web resmi Air Asia serta memposting di media social. Hingga pada akhirnya barulah pada tanggal 14 Mei 2019 refund tersebut dikembalikan ke rekening sdri. Dinda. Terhitung sudah hampir 1 tahun proses pengembalian dana tersebut.

Jika dilihat dari perspektif hukum Perlindungan Konsumen, maka perbuatan maskapai penerbangan terindikasi memiliki itikad tidak baik dalam memenuhi tanggung jawab yang mengakibatkan kerugian baik secara materil maupun immaterial serta melakukan wanprestasi terhadap perjanjian pengembalian dana (refund) terhadap konsumen. Dengan uraian di atas, penelitian ini bertujuan untuk mengetahui dan menganalisis bentuk perlindungan hukum terhadap konsumen yang mengalami penundaan pembayaran refund oleh maskapai penerbangan dan untuk mengetahui dan menganalisis bentuk tanggung jawab maskapai penerbangan terhadap refund dan mengetahui upaya penyelesaian apabila terjadi sengketa.

\section{METODE PENELITIAN}

Jenis penelitian yang digunakan adalah yuridis normative; suatu penelitian yang pembahasannya didasarkan undang-undang dan bahan-bahan hukum. Pendekatan penelitian menggunakan pendekatan perundang-undangan (the statue approach) yaitu menelaah semua undang-undang/ regulasi yang berkaitan dengan isu hukum yang sedang diteliti (Mahmud, 2009). Dalam penelitian ini, bahan hukum primer diperoleh dari KUHPerdata, Undang- undang No. 8 Tahun 1999 tentang Perlindungan Konsumen, Undang-Undang Nomor 1 tahun 2009 tentang Penerbangan, Permenhub RI Nomor 77 Tahun 2011 tentang Tanggung Jawab Pengangkut Angkutan Udara, dan Permenhub RI Nomor 185 
Tahun 2015 tentang Standar Pelayanan Penumpang Kelas Ekonomi Angkutan Negara Niaga Berjadwal dalam Negeri.

Bahan hukum dalam penelitian ini disajikan dalam bentuk interpretasi hukum, yaitu hasil penelitian dipaparkan dengan tujuan agar diperoleh suatu keseluruhan gambaran dan sistematik terutama mengenai tanggung jawab maskapai penerbangan dalam pengembalian dana ke konsumen akibat adanya pembatalan penerbangan yang selanjutnya menarik kesimpulan dari hal-hal yang bersifat khusus kepada hal yang berkaitan dengan rumusan masalah yang telah dipaparkan sebelumnya.

\section{HASIL DAN PEMBAHASAN}

\section{Bentuk Perlindungan Hukum terhadap Konsumen yang Mengalami Penundaan Pembayaran Dana Refund oleh Maskapai Penerbangan}

Perlindungan hukum terhadap konsumen di Indonesia dijamin dengan adanya Undang-undang Perlindungan Konsumen (UUPK). Maksud keberadaan UU No. 8 Tahun 1999 tentang Perlindungan Konsumen sebagai payung hukum adalah untuk menjamin kepastian hukum. Hak-hak konsumen perlu mendapatkan pembelaan dan perlindungan. Selain itu KUH Perdata dan peraturan lainnya yang terkait dapat memberikan kepastian hukum bagi konsumen sebagai bentuk perlindungan hukum dari negara kepada warga negaranya.

Refund adalah dikembalikannya uang pembayaran atau dana yang telah dilakukan oleh konsumen untuk membeli suatu produk. Produk yang dimaksud dapat berupa barang dan atau jasa. Pengembalian dana tersebut dapat disebabkan oleh batalnya transaksi dari salah satu pihak yang bertransaksi. Penundaan pembayaran refund melebihi batas ketentuan waktu yang telah ditetapkan karena kelalaian maskapai penerbangan yang berakibat pada munculnya kerugian konsumen merupakan faktor penentu adanya hak konsumen untuk mengajukan gugatan ganti rugi kepada maskapai penerbangan. Dasar gugatan bahwa maskapai penerbangan lalai jika perilaku maskapai penerbangan tidak sesuai dengan sikap hati-hati yang normal dan terbukti lalai serta penyebab kerugian yang timbul secara nyata.

Tuntutan ganti rugi tersebut akibat faktor kelalaian atau kesalahan pelaku usaha dapat juga diajukan dengan bukti-bukti lain yaitu pihak tergugat adalah pelaku usaha yang benar-benar mempunyai kewajiban untuk melakukan tindakan yang dapat menghindari timbulnya kerugian konsumen. Pelaku usaha tidak melaksanakan kewajibannya sebagaimana mestinya seperti menjamin kualitas produk sesuai dengan standar yang aman untuk digunakan atau dikonsumsi. Pelaku usaha yang lalai merupakan faktor yang menimbulkan adanya kerugian bagi konsumen (Samsul, 2004:47).

Ketentuan yang berhubungan dengan UUPK berdasarkan pada teori umum dalam hukum acara, yaitu asas kedudukan yang sama antara semua pihak yang berperkara yang biasa disebut asas audi et alterm partem. Para hakim harus memberikan ke pihak konsumen dan maskapai penerbangan beban yang seimbang dan patut sehingga masing-masing pihak memiliki kesempatan yang sama untuk memenangkan perkara. Setiap perkara harus jelas siapa yang menjadi subjek atau pelaku yang melakukan kesalahan.

Konsumen yang dirugikan akibat adanya penundaan pengembalian dana refund diawali dari jadwal penerbangan yang sudah ditetapkan dan selanjutnya dibatalkan oleh pihak maskapai penerbangan. Pembatalan jadwal penerbangan oleh maskapai penerbangan tidak diatur dalam Undang-undang No. 1 Tahun 2009 tentang Penerbangan namun dapat dilihat ketentuannya pada Peraturan Menteri Perhubungan Nomor 77 Tahun 2011 Pasal 12 ayat 1 dan 2.

Pasal tersebut menjelaskan bahwa pihak maskapai penerbangan berkewajiban untuk menginformasikan kepada penumpang selambat-lambatnya 7 (tujuh) hari kalender sebelum adanya pelaksanaan penerbangan dan calon penumpang tentu berhak untuk mendapatkan uang tiket yang telah dibayarkan sebelumnya jika terjadi pembatalan. Pembatalan penerbangan masuk dalam kategori keterlambatan angkutan udara sebagaimana Peraturan Menteri Perhubungan Nomor 77 Tahun 2011 Pasal 9 menyatakan bahwa keterlambatan angkutan udara sebagaimana dimaksud dalam Pasal 2 huruf e terdiri dari:

a. keterlambatan penerbangan [flight delayed);

b. tidak terangkutnya penumpang dengan alasan kapasitas pesawat udara (denied boarding passenger); dan

c. pembatalan penerbangan (cancelation of flight). 
Selanjutnya pengaturan mengenai pengembalian dana konsumen (refund) oleh pihak maskapai kepada penumpang apabila terjadi pembatalan penerbangan diatur dalam Pasal 10 Peraturan Menteri Perhubungan Nomor 185 tahun 2015 tentang Standar Pelayanan Penumpang Kelas Ekonomi Angkutan Negara Niaga Berjadwal dalam Negeri.

Jadi, mengenai pengembalian dana ke konsumen yang mengalami kerugian akibat penerbangan yang dibatalkan baik yang dilakukan oleh konsumen maupun maskapai penerbangan bahkan dalam hal terjadi forcemajeur sudah diatur dalam Peraturan Menteri Perhubungan Nomor 185 Tahun 2015. Peraturan ini juga mengatur tentang jangka waktu pengembalian uang tiket yang mewajibkan maskapai penerbangan mengembalikan uang tiket selambat-lambatnya 15 (lima belas) hari kerja sejak pengajuan jika konsumen membeli secara tunai dan paling lambat 30 (tiga puluh) hari kerja yang dihitung sejak pengajuan jika membeli menggunakan kartu kredit atau debit. Akan tetapi dalam Pasal 2 ayat (1) menyebutkan peraturan ini berlaku hanya bagi standar pelayanan untuk penumpang kelas ekonomi, sehingga kelas bisnis dan eksekutif tidaklah diatur mekanisme refund.

Menurut Yayasan Lembaga Konsumen Indonesia (YLKI) sejauh ini mekanisme refund diinterpretasikan berbeda oleh maskapai penerbangan. Dalam praktik, refund yang diterima penumpang bukanlah dalam bentuk uang, melainkan dalam bentuk voucher. Voucher dapat digunakan untuk membeli tiket pesawat selanjutnya. Seharusnya, pemahaman harus sama agar tidak menimbulkan masalah di lapangan. Memberi kepastian kepada konsumen, airlines tidak menafsirkan sendiri-sendiri.

Dalam hal tidak dipatuhinya ketentuan dalam Peraturan Menteri Perhubungan Nomor 185 Tahun 2015 oleh maskapai penerbangan, maka sanksi dapat dijatuhkan kepada pihak maskapai penerbangan sebagaimana Pasal 70 yang berbunyi:

Badan usaha angkutan udara niaga berjadwal dalam negeri yang melanggar ketentuan sebagaimana dimaksud dalam Peraturan ini, dikenakan sanksi sesuai dengan ketentuan peraturan perundang-undangan yang mengatur tentang sanksi administratif.

Namun Peraturan Menteri Perhubungan Nomor 185 Tahun 2015 tidak mengatur secara jelas mengenai sanksi yang dapat dijatuhkan bagi maskapai penerbangan yang melakukan pelanggaran. Oleh sebab itu, dalam rangka pengawasan terhadap penerapan peraturan perundang-undangan di bidang keselamatan dan keamanan penerbangan, perlu dilakukan penegakan hukum dan mengambil tindakan hukum dengan memberikan sanksi administratif terhadap setiap pelanggarannya melalui Peraturan Menteri Perhubungan (Permenhub) No. 30 Tahun 2015 tentang Pengenaan Sanksi Administratif Terhadap Pelanggaran Peraturan Perundang- Undangan Di Bidang Penerbangan. Jadi, bagi pihak maskapai penerbangan yang tidak mematuhi aturan refund yang diatur dalam Peraturan Menteri Perhubungan No. 185 Tahun 2015 dapat dikenakan sanksi administratif sebagaimana apa yang dinyatakan dalam Pasal 2 Peraturan Menteri Perhubungan No. 30 Tahun 2015. Pasal 23 Peraturan Menteri Perhubungan No. 30 Tahun 2015 mengatur lebih lanjut Prosedur pengenaan sanksi administratif dalam Peraturan Direktur Jenderal.

Terjadinya penundaan pengembalian refund yang melebihi jangka waktu yang telah ditetapkan tentu sangat merugikan konsumen. Oleh sebab itu Undang-Undang Nomor 8 tahun 1999 tentang Perlindungan Konsumen mengatur mengenai kewajiban maskapai penerbangan untuk mengembalikan ganti rugi dalam pasal 7 huruf f dan g. Dengan adanya penundaan refund oleh maskapai penerbangan ke konsumen yang memesan tiket perjalanan, maka dapat dikatakan bahwa maskapai penerbangan telah melakukan wanprestasi sebagaimana Undang-Undang Nomor 8 tahun 1999 tentang Perlindungan Konsumen menjelaskan dalam Pasal 16 yang berbunyi: Pelaku usaha dalam menawarkan barang dan/atau jasa melalui pesanan dilarang untuk: a. Tidak menepati pesanan dan/atau kesepakatan waktu penyelesaian sesuai dengan yang dijanjikan; b. Tidak menepati janji atas suatu pelayanan dan/atau prestasi.

Hapusnya suatu perikatan karena kebatalan atau pembatalan juga diatur dalam KUHPerdata Pasal 1446 sampai dengan Pasal 1456. Konsumen yang dirugikan akibat pembatalan suatu kontrak oleh maskapai penerbangan menyebabkan pengembalian hak-hak konsumen dalam hal ini pengembalian refund dengan jumlah penuh sebagaimana Pasal 1452 jelaskan. Bahkan pengembalian refund juga dapat ditambah dengan adanya biaya-biaya tambahan yang timbul seperti biaya telepon lokal dan interlokal yang dilakukan konsumen menghubungi maskapai penerbangan dan bunga akibat pembayaran dengan kartu kredit sebagaimana Pasal 1453 yang berbunyi, "dalam hal-hal tersebut 
dalam pasal 1446 dan 1449, orang yang terhadapnya tuntutan untuk pernyataan batalnya suatu perikatan dikabulkan, wajib juga mengganti biaya, kerugian dan bunga, jika ada alasan untuk itu".

\section{Bentuk Tanggungjawab Maskapai Penerbangan terhadap Dana Refund dan Upaya Penyelesaian Apabila Terjadi Sengketa}

Perlindungan hukum terhadap konsumen memiliki prinsip-prinsip yang bertujuan untuk memberikan layanan hukum kepada konsumen yang dirugikan disebabkan oleh maskapai penerbangan yang dapat dilihat dari Prinsip tanggung jawab berdasarkan unsur kelalaian atau kesalahan, Prinsip praduga untuk tidak selalu bertanggung jawab (Presumption of nonliability), Prinsip praduga untuk selalu bertanggung jawab (Pre-sumption of liability), Prinsip tanggung jawab dengan pembatasan (Limitation of liability), dan Prinsip tanggung jawab mutlak (Strict liability).

Maskapai selalu berusaha sebaik mungkin untuk memenuhi jadwal yang dipublikasikan. Maskapai sadar bahwa penjadwalan ulang/pembatalan tidak hanya mengganggu rencana bepergian tamu, namun juga mempengaruhi performan waktu maskapai juga. Garuda Indonesia selaku maskapai penerbangan BUMN menyatakan maklumat pelayanan (terlampir) bahwa Garuda Indonesia sanggup menyelenggarakan pelayanan dan menepati janji serta siap menerima sanksi sesuai peraturan perundang-undangan yang berlaku.

Akan tetapi, seperti maskapai penerbangan pada umumnya, terkadang penerbangan dibatalkan karena berbagai alasan, termasuk perubahan cuaca. Layanan Aspirasi dan Pengaduan Online Rakyat yang disingkat LAPOR adalah suatu sarana yang menjadi tempat aspirasi dan pengaduan berbasis media sosial yang diakses secara mudah dan terintegrasi dengan 81 Kementerian atau Lembaga, 5 Pemerintah Daerah, serta 44 BUMN yang ada di Indonesia. Pengembangan LAPOR dilakukan oleh Kantor Staf Presiden yang bertujuan untuk meningkatkan partisipasi masyarakat guna pengawasan program yang dijalankan pemerintah dan kinerja pemerintah dalam pelaksanaan pembangunan dan pelayanan publik menerima keluhan pelayanan Garuda Indonesia mengenai refund tiket atas pembatalan penerbangan yang sangat tidak jelas. Customer service Garuda Indonesia menjelaskan bahwa konsumen akan mendapatkan pengembalian atas refund tersebut kurang dari harga beli dikarenakan potongan administrasi lainnya. Pembatalan hanya dapat dilakukan melalui online karena membeli tiket secara online. Hingga 3 bulan lebih, refund tersebut masih tidak diterima konsumen. Berkali-kali konsumen menanyakan melalui email dan melalui telpon ke Call Center Garuda, hanya mendapatkan jawaban yang sama yaitu masih diproses, dan tidak adanya bagian/unit yang dapat menindaklanjuti masalah ini, bahkan customer service mengatakan bahwa konsumen hanya bisa pasrah menunggu karena mereka pun tidak tahu harus melakukan apa (https://www.lapor.go.id/laporan/detil/keluhan-mengenai-pelayanan-refund-tiket- garuda-indonesia diakses tanggal 2 Oktober 2019). Hal ini tentu tidak menunjukkan bentuk tanggung jawab maskapai penerbangan terhadap dana refund yang bertentangan dengan pernyataan Garuda pada Pasal 10 Persyaratan Pengangkutan Penumpang dan Bagasi bahwa "kami akan mengembalikan biaya Tiket atau bagian yang tidak terpakai dari Tiket, sesuai dengan aturan biaya atau Tarif yang berlaku dan Peraturan Menteri Perhubungan Indonesia Nomor PM 185 Tahun 2015 (PM185/2015) sebagaimana telah dirubah dari waktu ke waktu".

Yayasan Lembaga Konsumen Indonesia (YLKI) menyatakan, Lion Air menduduki peringkat pertama yang banyak diadukan masyarakat atau penumpang di antara lima maskapai besar lain. Konsumen pun mengeluhkan permasalahan pengembalian (refund) tiket karena berbagai alasan. Lion Air dalam situsnya menjelaskan bahwa pengembalian uang tiket dengan cara menghubungi call center atau melalui website yang dalam Conditions of Carriage dengan cara Pembatalan dan Pengembalian Uang E-Ticket yaitu anda dapat Hubungi Call Center kami atau kunjungi situs web kami untuk Pengembalian Uang/Pertukaran/Pencetakan Ulang E-Ticket. Lebih lanjut dalam syarat pengangkutan tersebut menjelaskan bahwa:

Lion Air berhak membatalkan atau mengubah rencana keberangkatan, jadwal, rute, pesawat terbang atau tempat transit penerbangan mana pun yang tiketnya telah dibayarkan, kapan pun dan dari waktu ke waktu, untuk alasan apa pun, tanpa pemberitahuan kepada penumpang yang terkena dampak dari perubahan tersebut, dan oleh karena itu, perusahaan pengangkut tidak bertanggung jawab kepada Penumpang atas pembatalan atau perubahan tersebut, baik yang disebabkan oleh Force Majeure. 
Conditions of Carriage maskapai Lion Air menunjukkan tidak adanya bentuk tanggung jawab dari maskapai penerbangan ini yang menekankan bahwa perusahaan pengangkut tidak bertanggung jawab kepada Penumpang atas pembatalan atau perubahan tersebut, baik yang disebabkan oleh Force Majeure. Hal ini tentu bertolak belakang dengan Pasal 10 ayat 3 pada Peraturan Menteri Perhubungan Nomor 185 tahun 2015 bahwa dalam hal terjadi force majeur maka penumpang bisa minta pengembalian biaya jasa angkutan udara (refund ticket).

Dalam kasus sdri. Dinda, pembatalan penerbangan yang dilakukan Air Asia disampaikan pemberitahuan Maskapai melalui email mengenai pembatalan penerbangan yaitu dengan memberikan salah satu pilihan dari layanan kompensasi yang ditawarkan seperti Ubah jadwal (move flight), Akun kredit (credit account), Ubah rute (reroute), dan Pengembalian dana (full refund). Dalam hal pengembalian dana (full refund) konsumen dapat mengirimkan permintaan pengembalian dana dengan tata cara penyerahan permohonan pengembalian dana konsumen disesuaikan dengan jenis pengembalian dana, kategori kasus (untuk eForm) dan dokumen yang diperlukan.

Jangka waktu proses pengembalian dana oleh maskapai penerbangan Air Asia umumnya membutuhkan waktu 30 hari kerja tergantung kebijakan masing-masing bank konsumen. Hal ini sudah sesuai dengan Peraturan Menteri Perhubungan Nomor 185 Tahun 2015 yang mengatur tentang jangka waktu pengembalian uang tiket yang mewajibkan maskapai penerbangan mengembalikan uang tiket paling lambat 30 (tiga puluh) hari kerja sejak dimulainya pengajuan jika membeli menggunakan kartu kredit atau debit. Dari tiga maskapai penerbangan yang dijelaskan sebelumnya yaitu Garuda Indonesia, Lion Air, dan Air Asia merupakan maskapai penerbangan besar yang mestinya profesional dan rendah kesalahan, namun keluhan timbul akibat lamanya pengembalian dana. Pengembalian dana yang melebihi jangka waktu yang telah ditentukan dapat merugikan konsumen, maka konsumen dapat mengajukan gugatan kepada maskapai penerbangan yang menimbulkan sengketa antara konsumen dan maskapai penerbangan.

Dalam kasus sdri. Dinda yang baru mendapat pengembalian dana melebihi batas waktu yang ditentukan itupun setelah melalui berbagai upaya yang menimbulkan biaya. Jika konsumen enggan melaporkan atau menggugat perilaku maskapai penerbangan atas keterlambatan yang dibuatnya tentu akan menjadi budaya maskapai penerbangan yang dapat menguntungkan dirinya. Maskapai penerbangan sudah jauh hari membuka pesanan tiket suatu perjalanan dengan promo penerbangan yang dibeli pada tanggal 25 Mei 2018 dengan jadwal keberangkatan tanggal 08 April 2019 dan jadwal pulang pada tanggal 15 April 2019 seharga Rp.2.490.000,00. Namun, pada tanggal 22 Oktober 2018 jadwal penerbangan tersebut dibatalkan. Ada rentang waktu 5 bulan sejak pembelian hingga pemberitahuan pembatalan. Dengan rentang waktu tersebut bahkan bisa saja lebih dan harga tiket dikalikan sejumlah penumpang yang memesan, tentu saja maskapai penerbangan diuntungkan karena telah mengumpulkan dan memanfaatkan dana secara cuma-cuma dari konsumen untuk kepentingan bisnis. Apalagi ditambah terjadi penundaan pengembalian dana yang dijanjikan hingga 180 hari sejak pengajuan opsi pembatalan dan itupun tidak sesuai dengan yang dijanjikan hingga ada rentang 12 bulan dari pembelian hingga pengembalian refund pada 14 Mei 2019. Maskapai penerbangan akan menjadikan calon konsumen sebagai sumber dana/modal bagi kepentingan bisnisnya.

Namun sengketa haruslah diselesaikan agar terciptanya hubungan baik antara maskapai penerbangan dan konsumen. Apabila konsumen dan pihak maskapai penerbangan tidak mampu menemukan bentuk penyelesaian yang tepat, maka perbedaan pendapat ini bisa berakibat buruk bagi keberlangsungan hubungan di antara keduanya (Rongiyati, 2019). Pihak konsumen dan maskapai penerbangan mendapatkan kembali hak-haknya oleh sebab terselesaikannya sengketa. Tujuan penyelesaian sengketa refund secara hukum untuk memberikan kenyamanan terhadap masing-masing pihak agar hak-haknya terlaksana dengan baik dan dengan begitu maskapai penerbangan dan konsumen merasakan keadilan. Penyelesaian sengketa umumnya terbagi menjadi dua yaitu melalui nonlitigasi dan litigasi. Penyelesaian melalui nonlitigasi bisa dengan pergantian kerugian secara langsung dan jalur BPSK, sedangkan melalui litigasi adalah dengan gugatan melalui lembaga peradilan umum.

1) Penyelesaian Sengketa Konsumen Pergantian Kerugian Secara Langsung Jika murni benar-benar kesalahan maskapai penerbangan dan bukan karena kesalahan yang dilakukan oleh konsumen, maka tuntutan pergantian kerugian ini dapat dilakukan. Pasal 19 UUPK memberikan kesempatan ke maskapai penerbangan untuk membuktikan bahwa dirinya tidak bersalah melainkan kesalahan ada pada konsumen, jika maskapai penerbangan berhasil membuktikan bahwa maskapai penerbangan tidak melakukan kesalahan, namun kesalahan 
ada pada konsumen, maka maskapai penerbangan tidak ada kewajiban untuk membayar atau mengganti kerugian tersebut.

2) Penyelesaian Sengketa Konsumen Melalui BPSK

Berdasarkan pasal 52 huruf a UUPK bahwa BPSK akan menyelesaikan sengketa konsumen dengan jalan melalui: 1) mediasi yaitu cara penyelesaian sengketa yang fleksibel dan tidak mengikat serta melibatkan pihak netral yaitu mediator; 2) konsiliasi yaitu yaitu menyerahkan kepada pihak ketiga untuk memberikan pendapatnya tentang sengketa yang disampaikan oleh pihak konsumen dan maskapai penerbangan, akan tetapi pendapat dari konsiliator tidak mengikat sebagaimana yang ada pada arbitrase; dan 3) arbitrase yaitu pihak konsumen dan maskapai penerbangan menyetujui dilaksanakan penyelesaian sengketa yang dialami kepada pihak netral yang konsumen dan maskapai penerbangan pilih untuk membuat keputusan terselesaikannya sengketa yang sedang mereka hadapi. UUPK tidak menentukan pemisahan tugas anggota BPSK yang mengakibatkan para anggota BPSK dapat berperan sebagai konsiliator, aribitrator, maupun mediator (Miru \& Yodo, 2008:125).

3) Penyelesaian Sengketa Konsumen Melalui Jalur Litigasi

Sebagaimana yang telah dijelaskan oleh UUPK gugatan konsumen terhadap maskapai penerbangan dapat diproses melalui lembaga Peradilan Umum yaitu dengan cara gugatan individual dan gugatan perwakilan kelompok (class action). Pasal 46 UUPK membolehkan ketika ada sekelompok konsumen yang dirugikan dalam hal yangsama yaitu pengembalian refund oleh maskapai penerbangan maka dapat mengajukan class action karena adanya kesamaan fakta dan dasar hukum antara satu orang atau lebih mewakili kelompok tertentu.

\section{SIMPULAN DAN SARAN}

\section{Simpulan}

Pengembalian dana (refund) ke konsumen akibat pembatalan penerbangan diatur dalam Peraturan Menteri Perhubungan No. 185 Tahun 2015 yaitu mewajibkan maskapai penerbangan mengembalikan uang tiket selambat- lambatnya 15 (lima belas) hari kerja sejak pengajuan jika konsumen membeli secara tunai dan selambat-lambatnya 30 (tiga puluh) hari kerja sejak pengajuan jika membeli menggunakan kartu kredit atau debit. Penundaan refund oleh maskapai penerbangan ke konsumen merupakan bentuk wanprestasi sebagaimana Pasal 16 Undang-Undang Nomor 8 tahun 1999 tentang Perlindungan Konsumen. Pengembalian refund juga dapat ditambah dengan adanya biaya-biaya tambahan yang timbul yang diderita konsumen sebagaimana Pasal 1453 KUHPerdata. Maskapai penerbangan yang tidak mematuhi aturan refund dalam Peraturan Menteri Perhubungan No. 30 Tahun 2015 dapat dikenakan sanksi administratif berupa peringatan, pembekuan, pencabutan, dan/atau denda adminstratif.

Kemudian, bentuk tanggung jawab maskapai penerbangan dalam refund memiliki kebijakan yang berbeda-beda. Garuda Indonesia dengan jelas menyatakan bahwa pengembalian dana konsumen mengikuti Peraturan Menteri Perhubungan No. 185 Tahun 2015, sementara Lion Air tidak jelas mengacu pada aturan pemerintah. Air Asia dalam hal pengembalian dana (full refund) konsumen memberikan jangka waktu proses pengembalian dana umumnya membutuhkan waktu 30 hari kerja tergantung kebijakan masing-masing bank konsumen. Hal ini sudah sesuai dengan Peraturan Menteri Perhubungan Nomor 185 Tahun 2015 yang mengatur tentang jangka waktu pengembalian uang tiket yang mewajibkan maskapai penerbangan mengembalikan uang tiket selambat-lambatnya 30 (tiga puluh) hari kerja sejak pengajuan jika membeli menggunakan kartu kredit atau debit. Konsumen dapat mengajukan gugatan kepada maskapai penerbangan apabila pengembalian dana melebihi jangka waktu yang ditentukan. Penyelesaian sengketa konsumen dapat dilakukan dengan cara 1) Pergantian kerugian secara langsung; 2) Melalui BPSK yang menurut Pasal 52 huruf a UUPK akan menyelesaikan sengketa konsumen dengan jalan melalui mediasi, konsiliasi dan arbitrase; 3) Penyelesaian sengketa konsumen melalui jalur litigasi.

\section{Saran}

Meskipun jangka waktu refund sudah diatur dalam Peraturan Menteri Perhubungan Nomor 185 Tahun 2015 dan sanksi bagi maskapai penerbangan yang tidak mengikuti peraturan ini dapat dikenakan sanksi administratif yang diatur dalam Peraturan Menteri Perhubungan No. 30 Tahun 2015, namun dalam implementasinya banyak konsumen yang dirugikan akibat penundaan refund. Agar dapat 
memberikan perlindungan hukum, maka diperlukan penerapan peraturan yang tegas dam ketersediaan akses poin pengaduan yang dikelola oleh otoritas bandara, selain itu memperberat kewajiban refund dengan pengembalian dana penuh berikut biaya-biaya tambahan yang timbul seperti biaya telepon lokal dan interlokal yang dilakukan konsumen menghubungi maskapai penerbangan dan bunga akibat pembayaran dengan kartu kredit. Maskapai penerbangan agar selalu berusaha sebaik mungkin untuk memenuhi jadwal yang dipublikasikan dan melaksanakan pengembalian dana ke konsumen sesuai dengan aturan yang telah dibuat pemerintah untuk menghindari konflik pengembalian dana. Konsumen juga tidak perlu ragu untuk menuntut haknya dan memberikan warning kepada pelaku usaha lainnya agar lebih mengedepankan perlindungan konsumen daripada profit oriented semata. Jika terjadi sengketa antara konsumen dan pelaku usaha, maka terlebih dahulu menggunakan caracara nonlitigasi agar tercipta hubungan baik antara maskapai penerbangan dan konsumen. Apabila cara nonlitigasi tidak dapat menyelesaikan sengketa ini, maka konsumen dapat menempuh penyelesaian sengketa melalui jalur litigasi.

\section{DAFTAR PUSTAKA}

Kristiyanti, C. T. S. (2019). Hukum Perlindungan Konsumen (8th ed.). Jakarta: Sinar Grafika.

Mahendrawati, N. L. M. (2018). Larangan Monopoli dan Persaingan Tidak Sehat dalam Usaha Perdagangan di Indonesia. Malang: Surya Pena Gemilang.

Mahmud, M. P. (2009). Penelitian Hukum. Jakarta: Kencana Predia Media Grup.

Miru, A., \& Yodo, S. (2008). Hukum Perlindungan Konsumen. Jakarta: Raja Wali Pres.

Rongiyati, S. (2019). Pelindungan Konsumen dalam Transaksi Dagang Melalui Sistem Elektronik (Consumer Protection in E-Commerce). Negara Hukum: Membangun Hukum Untuk Keadilan Dan Kesejahteraan, $10(1), 430-447$.

Samsul, I. (2004). Perlindungan Konsumen, Kemungkinan Penerapan Tanggung Jawab Mutlak. Jakarta: BP Universitas Indonesia.

https://www.lapor.go.id/laporan/detil/keluhan-mengenai-pelayanan-refund- tiket-garuda-indonesia diakses tanggal 2 Oktober 2019.

https://m.liputan6.com/bisnis/read/2166024/lion-air-dan-refund-tiket-paling- banyak-diadukan-konsumen-keylki diakses tanggal 7 Oktober 2019 